\title{
Some Aspect of Reproductive Biology on the Effect of Pollution on the Histopathology of Gonads in Puntius Javanicus from Mas River, Surabaya, Indonesia
}

\author{
Shobikhuliatul J J \\ Graduate Student, Faculty of Fisheries and Marine science \\ University of Brawijaya, Malang
}

Sri Andayani

Faculty of Fisheries and Marine science

University of Brawijaya, Malang, Indonesia

Jerome Couteau

Toxem, University of Le Havre, France

Yenny Risjani

Central Laboratory of Life Sciences (LSIH)

University of Brawijaya, Malang, Indonesia

Christophe Minier

Laboratory of Ecotoxicology (LEMA)

University of Le Havre, France

Received: March 10, 2013 Accepted: March 25, 2013

doi:10.5296/xxx.vxix.xxx URL: http://dx.doi.org/10.5296/xxx.vxix.xxx 


\section{Mll Macrothink}

\section{Abstract}

The present work aimed to study some aspect of the reproductive biology of the P. javanicus with emphasis on histopathology abnormalities of gonads and intersex problems. Fish samples of Puntius javanicus (local name:tawes) were collected from Mas River on the Surabaya downtown whereas highly pollution. Fishes were identified for morphological abnormality and gonad organs were evaluated. Histological preparation was done to observe the gonad condition. This report reveals that $20 \%$ male P. javanicus were found to be feminized on July 19, 2012 collection from that river. Some histological samples indicated the presence of testis-ova in fish gonad, which indicated the occurrence of intersex of this species. The above finding suggests that greater attention needs to be given to xenobiotic pollutants and endocrine disrupting chemicals problems.

Keywords: Mas River, Pollution, Reproductive biology, Histopathology, Gonads, Intersex

\section{Introduction}

Mas River is a branching rivers and the lower reaches of the Brantas River Basin (Surabaya River) which located in the city of Surabaya and flowing toward the coast north through the center of Surabaya and empties into the Madura Strait. Mas River has small current relatively to substrate base muddy and rocky generally. This river is approximately $13 \mathrm{~km}$ distance from Wonokromo up to estuary, between $25 \mathrm{~m}$ to $35 \mathrm{~m}$ of wide with a depth ranging from $1.5 \mathrm{~cm}$ to $3.5 \mathrm{~m}$ (Bayu, 1997). Maximum discharge of water was on March (49.34 $\left.\mathrm{m}^{2} / \mathrm{s}\right)$ and the minimum was on October $\left(1.88 \mathrm{~m}^{2} / \mathrm{s}\right)$. Mas River's flow splitting Surabaya city with a variety of human activities, such as industrial activities, settlements, a boat tour, water sport and other extremely dense human activities. Bayu, (1997) recorded that Mas River's water had $28^{\circ} \mathrm{C}$ of temperature with $746 \mathrm{NTU}$ of turbidity and $\mathrm{pH}$ of 6.6. The water of the river became the main source for the PDAM Surabaya and industries along Surabaya River. Heavy metal content exceeds water quality standards with the highest range for Cd value of 0.007 to $0.039 \mathrm{mg} / 1, \mathrm{Hg}$ at $0.031-0.056 \mathrm{mg} / 1$ and $\mathrm{Pb}$ at 0.068 to $0.752 \mathrm{mg} / 1$ (Putri et al., 2011).

There are about 600 factories spread along the Brantas River but only 60 which having standard level of waste processing system (Ecoton, 2008). Water quality in the Mas River is one of the worst compared to other branching sites at the Brantas River flow. Some sources of waste are originated from household activities, markets, drainage and non-domestic activities around the river. The Mas River main function today is as a sewage and drainage channels in the city of Surabaya, especially those in the middle. Putri et al. (2011) has made measurements of some water quality parameters in the Mas River. Several water quality parameters measured including DO, BOD, COD, TSS and NH3-N (Table 1).

Table 1. Water quality parameters in the Mas River (Putri et al., 2011)

\begin{tabular}{|l|l|l|}
\hline Parameter & Value $(\mathrm{mg} / \mathrm{l})$ & Water Quality Standards \\
\hline DO & $1.27-3.04$ & $4^{*}$ \\
\hline BOD & $9-37$ & $3^{*}$ \\
\hline COD & $16-60$ & $25^{*}$ \\
\hline TSS & $142-182$ & $50^{*}$ \\
\hline NH3-N & $0.41-1.38$ & $\leq 0.02^{*}$ \\
\hline
\end{tabular}


*Indicates that the value exceeds the max allowed by Indonesian Government (PP no 82 2001) for fisheries activity

The chemical pollutants distributes through the aquatic environment may give impact to aquatic organisms and found to interact with the vertebrate endocrine system. Xenobiotics thought to act as endocrine disrupters, characterized as the pollutants as a result of anthropogenic impacts on the environment, which is central to the study of research on ecotoxicology (Allner et al., 2010). EDC phenomenon has been reported and occurred in some parts of the world. In a small creek downstream of a paper mill discharging bleached kraft mill effluent had been found the presence of masculinised female mosquito fish (Gambusia affinis) that induced male secondary sexual characteristics (Howell et al., 1980). That study appeared that the effluent contained an androgenic chemical or mixture of chemicals. In the Red River of the North in North Dakota, USA has been reported female channel fish (Tetalurus punctatus) exhibiting male secondary sexual characteristics (Hegrenes, 1999). He stated that there are no paper mills discharging effluent into this river, although it does receive waste water from a sewage treatment plant and a sugar beet processing plant. Exposure to treated sewage effluent has also been associated with deleterious effect on gonad differentiation and development in various species of fish and the abnormal development (feminization) of secondary sexual characteristics in male mosquito fish (Gambusia affinis) in Australia (Batty and Lim, 1999). Intersex in the cyprinid fish commonly occurred at lowland rivers in the United Kingdom. The fish often have both male and female reproductive ducts and many also have female germ cells (oocytes) within a predominantly male testis. In contrast to the effects observed in female cyprinid fish, there was higher incidence of oocyte atresia and a slight, but statistically significant, lower fecundity in effluent-exposed fish compared with female from the references sites (Jobling et al., 2002). In Taiwan, the intersex tilapia collected from Era-Jiin River were mostly likely caused by endocrine disrupting chemicals, especially when the ratio of intersex was $50 \%$ and these fishes were natural inhabitants on this river (Sun and Tsai, 2009).

Our study took place at the Mas River located in the Brantas Deltas area, which received water flow from the Brantas. The past fishes collection from the Brantas River has been done in 1997 by Risjani et al. (1998). There were more than 50 fishes species collected from the Brantas River. But in 2011, the number of species decreased. The number of fish species on the Brantas River downstream segments recorded by ECOTON (Ecological Observation and Wetlands Conservation) (2011) found 30 species of freshwater fish, one of which is Bader putihan or Tawes (Puntius javanicus). The causative effect of the decrease of fish species number was pollutant from anthropogenic activities (Risjani et al, 2012). In relation with these huge potential impacts on downstream Brantas River basin, especially from domestic waste, household industrial activities, agriculture and the chemical industry, it is necessary to study what extent the effect of pollutants on fish gonad histopathology P. Javanicus in the Mas River, which is expected to provide benefits and used as an indicator of ecotoxicology. 


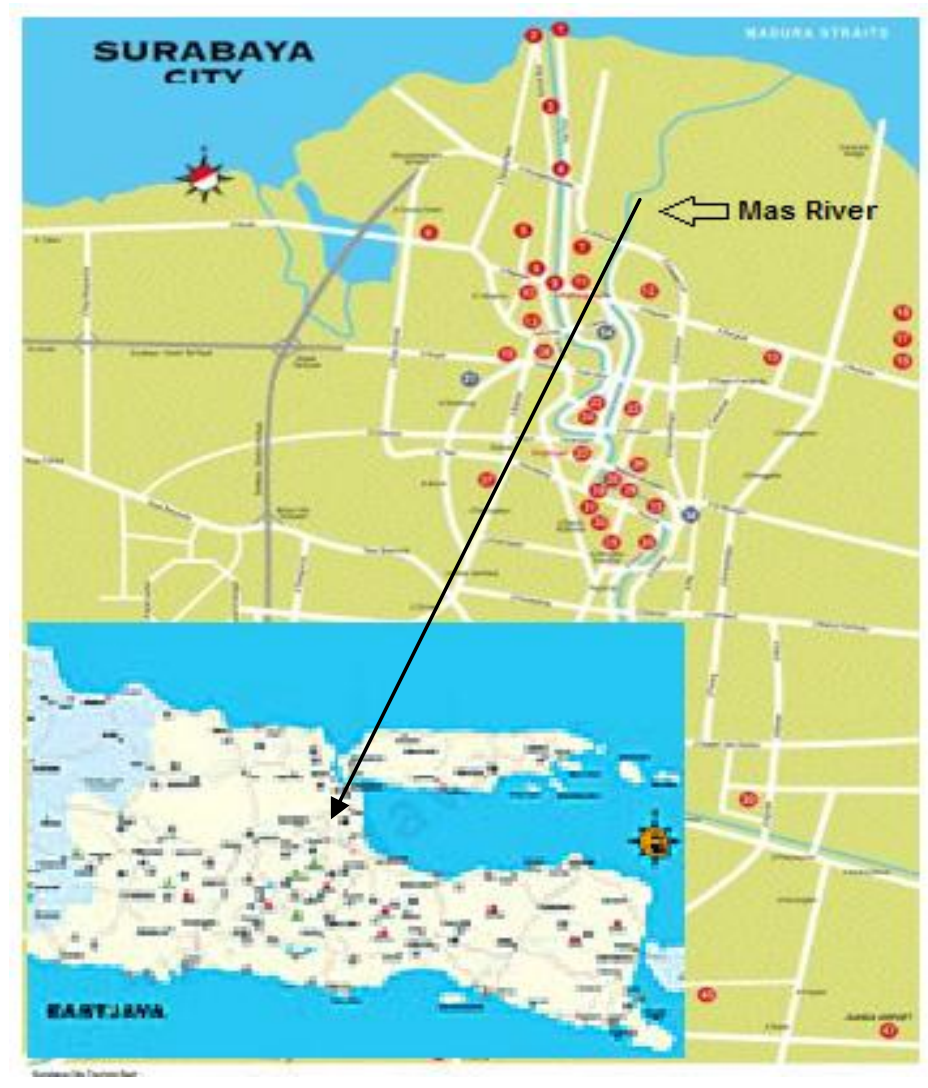

Figure 1. Location of the rivers and sampling station (arrow)

\section{Materials and Methods}

In order to study the effects of pollution on fish reproduction, samples were collected from along the Mas River (Fig. 1) using gill net (with 3-cm stretch mesh) on July 19, 2012. In total, 10 P. javanicus were collected. Fish were identified (length, fish weight, gonad weight) and sexed for morphological evaluation of gonadal maturation. Linear allometric model (LAM) used to calculate the parameters $\mathrm{a}$ and $\mathrm{b}$ by measuring changes in weight and length. Correction of error in the average weight change from logarithmic unit used to predict weight at length parameter according to the allometric equation: $\mathbf{W}=\mathbf{a} \mathbf{L}^{\mathbf{b}}$ (De Roberts and William, 2008). $\mathbf{W}$ is the weight of fish $(\mathrm{g}), \mathbf{L}$ is the total length of fish $(\mathrm{mm})$, a and $b$ are parameters. The relative weight $(\mathrm{Wr})$ and coefficient $(\mathrm{K})$ factor conditions was used to evaluate the condition of each individual factor. The relative weight $(\mathrm{Wr})$ was determined by the equation: $\mathbf{W}_{\mathbf{r}}=\left(\mathbf{W} / \mathbf{W}_{\mathbf{s}}\right) \mathbf{x} 100$ (Rypel and Richter, 2008). $\mathbf{W}_{\mathbf{r}}$ is the relative weight, $\mathbf{W}$ weight of each fish, and $\mathrm{W}_{\mathrm{s}}$ is the standard weight predicted from the same sample as calculated from the length-weight of regression combined with the distance between species: $\mathbf{W}_{\mathbf{s}}=\mathbf{a} \mathbf{L}_{\mathbf{b}}$. Fulton condition coefficient (K) was determined by formula: $\mathbf{K}=\mathbf{W} \mathbf{L}^{\mathbf{- 3}} \times \mathbf{1 0 0}$ (Okgerman, 2005). $\mathbf{K}$ is the condition factor, $\mathbf{W}$ is the weight $(\mathrm{g}), \mathbf{L}$ is the length $(\mathrm{mm})$ and ${ }^{-3}$ is the coefficient lengths to ensure that the value of $\mathbf{K}$ tends to 1 . The gonadosomatic index was calculated for all the specimens as the percentage of gonad weight to the gutted fish weight. Gonadosomatic Index $=$ [gonad weight $(\mathrm{g}) /$ body weight $(\mathrm{g})]$ x 100 (Mazrouh dan Mahmoud, 2009). Gonads were collected by dissecting the fish and inserted into bottle film containing $10 \%$ formalin 


\section{Macrothink}

solution in order preserving, then stored into the coolbox to be taken to the laboratory for histological preparation.

\section{Histological Preparation}

\subsection{Fixation}

Gonad was put into $10 \%$ formalin and allowed to stand for at least 24 hours. Cut across and put into tissue tex.

\subsection{Dehydration}

Gonad was entered consecutive into a solution of Alcohol 70\% I, 70\% II, 90\% I, 90\% II, Alcohol Absolute I and II for 45 minutes respectively.

\subsection{Clearing}

Gonad was entered into the solution of pure xylol I, II and III for 45 minutes respectively.

\subsection{Infiltration}

Gonad was put into liquid which content of xylol : paraffin (1:1) for 20 minutes, and then enter the liquid paraffin I, II and III for 20 minutes in the oven at $60^{\circ} \mathrm{C}$ respectively.

\subsection{Embedding (sample planting) and blocking (blocks making)}

Gonad was put into paraffin solution I, II for 45 minutes respectively. Then the samples were taken and placed on a stainless steel mold that was heated on a hot plate. After the sample laid out above the mold, the liquid paraffin was poured over the mold until sample piece immerse all.

\subsection{Sectioning (slicing) and laying down on a glass object}

Blocks were fitted on the pre-set microtome 5-6 microns thick. The cutting was done to low and constant, when the slices have reached the sample, then slices was transferred into a basin of cold water and placed on glass objects that have been coded, and dipped into a water bath in order to the sample expands. Preparations in glass objects were dried on a hot plate with a temperature of $28{ }^{\circ} \mathrm{C}$.

\subsection{Affixing}

Gluing by using the albumin and glycerin in the ratio of 1:1 and was stored in a box stock for 1 day

\subsection{Deparafinisation}

Deparafinisation were done to remove the paraffin by putting down into xylol for 10 minutes.

\subsection{Staining (coloring)}

Histological preparations that have been dried was moved and processed for haematoxylin and eosin staining: 
a) The xylol on histological preparations was sucked by using the filter paper. Then row was inserted into alcohol 96\%, 90\%, 80\%, 70\%, 60\%, 50\%, 40\% and 30\% respectively for 5 minutes then into distilled water for 5 minutes. And was washed by water flows for 2 minutes approximately.

b) The histological preparation was put into haematoxylin for 4 minutes.

c) The histological preparation was washed by water flows for 10 minutes.

d) The histological preparation was inserted into the distilled water and $50 \%$ alcohol, $60 \%, 70 \%, 80 \%, 90 \%$ and $96 \%$, respectively some dyes.

e) The histological preparation was inserted in eosin for 1.5 minutes.

f) The histological preparation was inserted on alcohol 70\%, 80\%, 90\% and 95\%.

g) The histological preparation was dried and put into xylol for 15 minutes.

h) Canada balsam was poured and covered with a cover glass.

\subsection{Mounting (Closure) and Labeling}

The histological reparations were closured by using the cover glass and give identity to the preparations.

\section{Result and Discussion}

\subsection{Fish Morphology}

Puntius caught at the time of the study were 10 individuals with unbalanced gender ratio, with composition of 4 males and 6 females. There were unequal number of male and female fish caught allegedly due to differences in behavior and catching factors, such as male fish are active, causing the arrest of opportunity is smaller than the female (Fatimah, 2006). Size of fish body length varies between 110-155 mm with the weight range of 30.5 to $53 \mathrm{~g}$. Male fish caught at $130-155 \mathrm{~mm}$ in length and weighing 0.35 to $0.54 \mathrm{~g}$. Meanwhile, female fish were caught on the length of $110-150 \mathrm{~mm}$ and weight of 30.5 to $52 \mathrm{~g}$ (Table 2).

Table 2. Morphological deformities and other abnormalities in P. javanicus collected in the Mas River

\begin{tabular}{|l|l|r|r|}
\hline \multicolumn{1}{|c|}{ Item } & \multicolumn{1}{|c|}{ Description } & \multicolumn{1}{|c|}{$\begin{array}{c}\text { Percentage (\%) of } \\
\text { prevalence }\end{array}$} & $\begin{array}{c}\text { Number of fish } \\
\text { discovered among these } \\
\text { 10 P. javanicus }\end{array}$ \\
\hline Fin and body surface & $\begin{array}{l}\text { Ripped fin, body surface } \\
\text { slimy }\end{array}$ & 80 & 8 \\
\hline Scale & Chipped, necrosis & 40 & 4 \\
\hline Liver & Chocolate color & 90 & 5 \\
\hline Gill & $\begin{array}{l}\text { Mucus secretion, necrosis, } \\
\text { pale }\end{array}$ & 50 & \\
\hline Body weight $(\mathrm{g})$ & $30.5-53 \mathrm{~g}$ & & \\
\hline Gonad weight $(\mathrm{g})$ & $0,11-0,54 \mathrm{~g}$ & & \\
\hline Body Length $(\mathrm{mm})$ & $110-155 \mathrm{~mm}$ & & \\
\hline
\end{tabular}




\subsection{Reproductive Biology of Fish}

a. Length Weight Relationship

Table 3. Length weight relationship and condition factor of tawes fish (P. javanicus)

\begin{tabular}{|l|r|r|r|}
\hline \multicolumn{1}{|c|}{ Parameter } & \multicolumn{1}{c|}{ Value } & Average & Standar deviation (SD) \\
\hline Total length (TL) mm & $110-155$ & 135 & 15.63 \\
\hline Weight (W) g & $30.5-53$ & 45.15 & 7.86 \\
\hline The predicted weight (Ws) & 45.15 & & 17,40 \\
\hline Relative weight (Wr) & $67.55-117.39$ & 100 & 0.00 \\
\hline Fulton condition factor (K) & $0.67-1.17$ & 0.002 & \\
\hline Index coefficient of determination (R2) & 0.876 & & \\
\hline Index correlation coefficient (r) & 0.936 & & \\
\hline b value & 1.515 & & \\
\hline
\end{tabular}

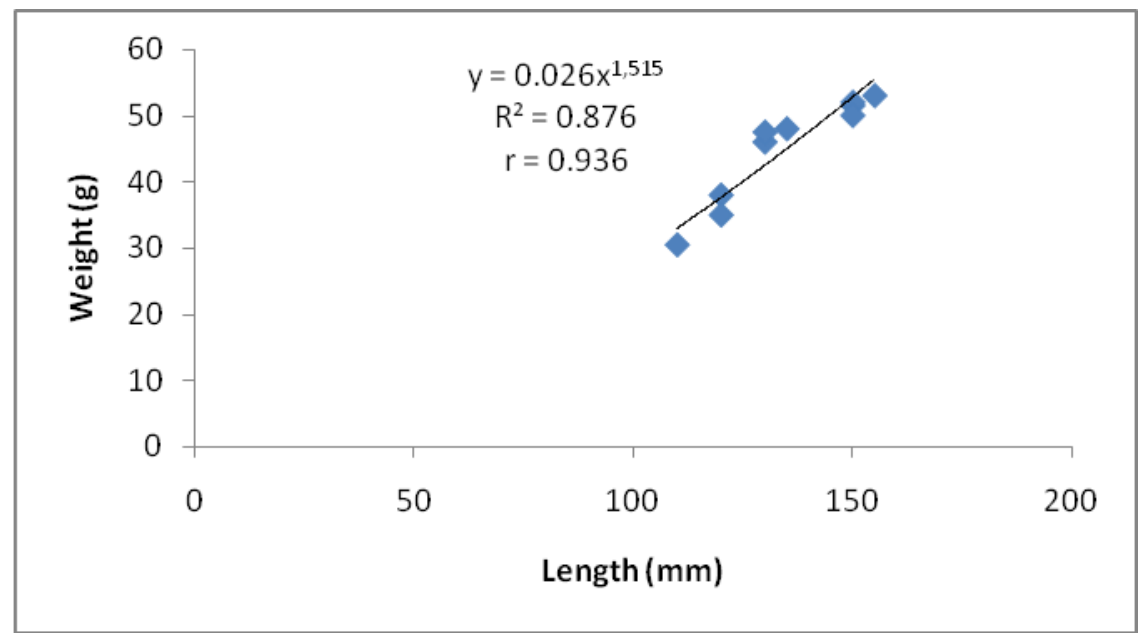

Figure 2. Relation Length -Weight chart of tawes ( $P$. javanicus)

Length weight relationship of $P$. javanicus can be seen from the value of correction (r) of 0,936 (Tabel 3 and Figure 2). According to Walpole (1995) value of correlation coefficient (r) close to 1 , so there is a strong linear relation between body length and weight of fish. Length weight relationship of fish varies depending upon the condition of life in aquatic environment. Ideally, the regression coefficient ' $b$ ' of a fish should be very close to 3.0 (Allen, 1938).

2. Stage of Gonad maturity and Gonadosomatic Index

Table 4. Gonadosomatic Index of P. javanicus caught from Mas River

\begin{tabular}{|l|r|r|r|}
\hline Sex & Weight $(\mathrm{g})$ & Gonad Weight $(\mathrm{g})$ & GSI \\
\hline Male & 53 & 0,54 & 1,018868 \\
\hline Male & 51,5 & 0,54 & 1,048544 \\
\hline Female & 52 & 0,5 & 0,961538 \\
\hline Female & 38 & 0,3 & 0,789474 \\
\hline Female & 48 & 0,41 & 0,854167 \\
\hline Female & 30,5 & 0,11 & 0,360656 \\
\hline Female & 35 & 0,29 & 0,828571 \\
\hline Male & 46 & 0,35 & 0,76087 \\
\hline Female & 47,5 & 0,35 & 0,736842 \\
\hline Female & 50 & 0,51 & 1,02 \\
\hline
\end{tabular}




\section{Ml Macrothink}

Fishes ( $P$. javanicus) which were caught having gonadosomatic ranges from 0.360656 to 1.048544 (Table 4). These results suggest that the greater the value weight, the greater the value gonad weight (Effendi, 1997). This results had the same value like Slamet et al. (2010) that the heavier the weight of Plectropoma laevis, the more severe gonad although there are also some fish that show different results, in which there are fish that have a relatively higher weight but has a smaller gonad weight.

Table 5. Criteria for Fish Gonad Maturity Stage (Puntius schwanefeldi Bleeker) (Siregar, 1993).

\begin{tabular}{|c|l|l|}
\hline Gonad Maturity Stage & \multicolumn{1}{|c|}{ Female } & \multicolumn{1}{|c|}{ Male } \\
\hline I & $\begin{array}{l}\text { Ovary like thread length to the } \\
\text { front body cavity, clear colors, } \\
\text { smooth. }\end{array}$ & $\begin{array}{l}\text { Testis like yarn, shorter (limited) } \\
\text { and visible edges in the body } \\
\text { cavity, clear colors. }\end{array}$ \\
\hline II & $\begin{array}{l}\text { Ovarian size larger, darker } \\
\text { colors yellow, egg yet to be seen } \\
\text { clearly with eyes. }\end{array}$ & $\begin{array}{l}\text { Larger testes size, white as milk, } \\
\text { a clearer form than the stage I. }\end{array}$ \\
\hline
\end{tabular}

Gonad maturity stage of $P$. javanicus were observed at stage II (Table 5). At stage II, female gonads are larger than stage I, fill a third of the abdominal cavity, light brown. Granules eggs still cannot be seen with eyes. For the male, the gonads have a larger size than stage I, and white (Table 5) (Siregar, 1993).

\subsection{Histological Studies}

According to histological analyzed from the male gonad, Testis-ova (the presence of oocytes in the testis) were observe in two individuals collected from Mas River (Fig.3a and 3b). The oocytes of the perinucleolus stage that are the characteristic of the testis-ova were scattered in the testis. The testis of $P$. javanicus indicated severe degenerative, collapsing and necrotic changes in both the wall and the cellular elements of the seminiferous tubules with focal areas of fibrosis (Fig.3b and 3c). The deformed testis showed tissue necrosis, congestion of capillaries and vacuolated leyding cells. It also shows disrupted testicular tissue with spacious fibrous interstitial connective tissue with fibroblast and edema. On the female gonad, the fish was at stage II of gonad maturity with atretic oocytes characterized by breaking down zona radiata and proliferation of granulosa layer which invade the dead ova and vacant space in the ovary (Fig.3d). 


\section{$\Lambda$ Macrothink}
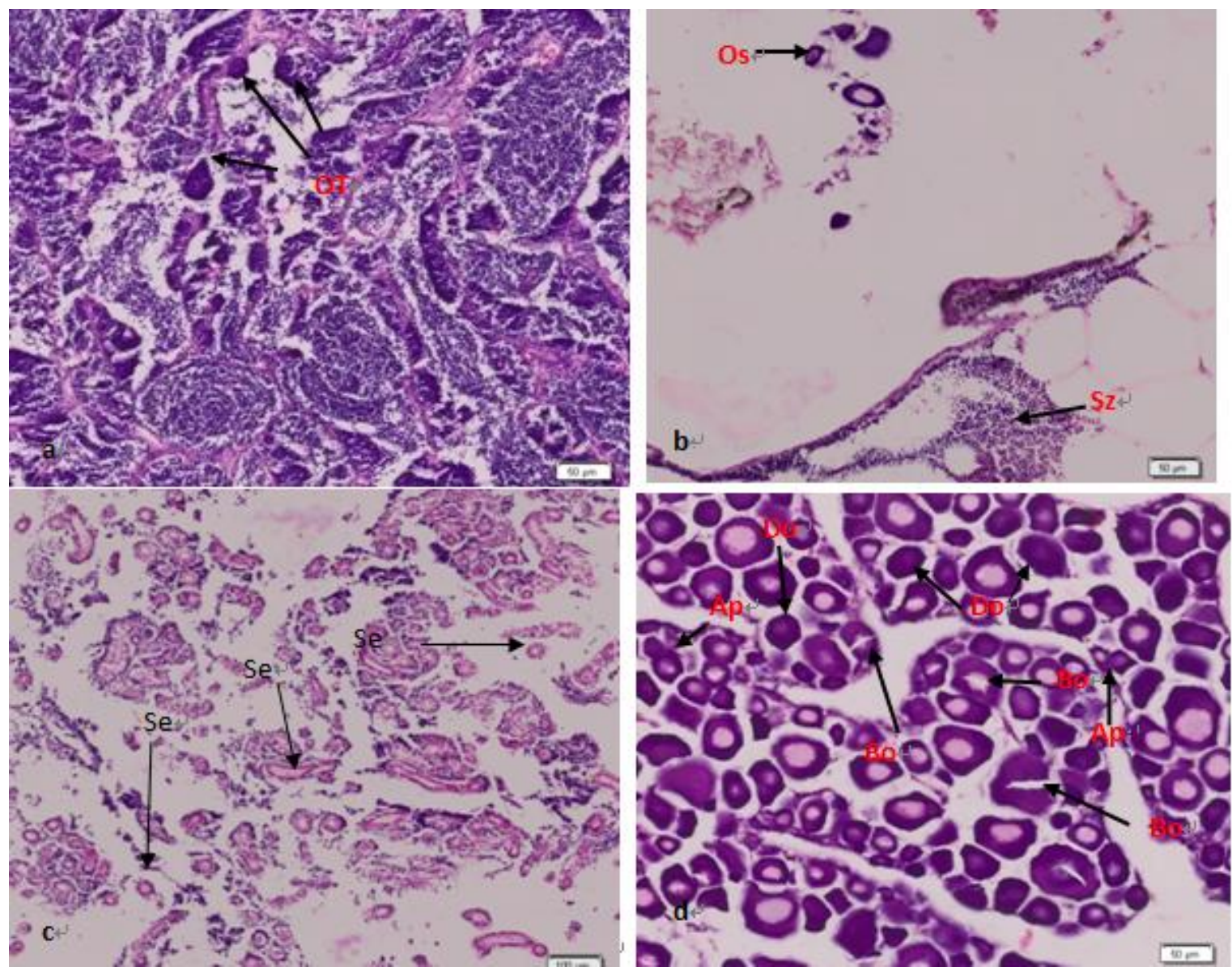

Figure 3. Gonad of Tawes fish from polluted area in Mas, Surabaya. (a) T-O: testis-ova on male gonad (b) T-O: testis-ova in male gonad (c) disrupted testicular tissue with interstitial connective tissue on male gonad (d) destroyed oocyte with atretic perinucleolus oocytes and breaking down oocytes on female gonad. O: ovary, T: testes, Se: seminiferus lobules, Ap: atretic perinucleolus oocytes, Do: destroyed oocytes, Bo: breaking down oocytes.

\section{Discussion}

\subsection{Fish Morphology}

The present study recorded the maximum size of $P$. javanicus as $15.5 \mathrm{~cm}$ TL, which were lower than the maximum recorded value of $37 \mathrm{~cm}$ by ECOTON (2011). However, Rahman et al. (2012) reported the maximum TL for P.sophore form Chanal Beel, North-Central Bangladesh, India as $9.02 \mathrm{~cm}$. In addition, the maximum weight of $P$. javanicus observed in this study $(53 \mathrm{~g})$ was lower than the maximum recorded value of $750 \mathrm{~g}$ in other sites of the Brantas River flow (ECOTON, 2011). Archarya and Iftekhar (2000) recorded the maximum value of P.sophore as $70 \mathrm{~g}$ in Maharastra, India.

\subsection{Reproductive Biology of Fish}

Based on the graph of length $(\mathrm{x})$ and weight $(\mathrm{y})$ obtained $\mathrm{y}=0.026 \mathrm{x}^{1.515}$ of regression equation. $\mathrm{b}$ value in the regression equation is $1.515(\mathrm{~b}<3)$ which means that the fish has a negative allometric growth type. It shows the state of the bony fish as in length faster than the increment 
weight. In contrast, Rahman et al. (2012) recorded the b value of $P$. sophore as 3.322 in Chanal Beel, North-Central Bangladesh, India. The coefficient (b) from their studies indicated positive allometric growth with pool barb in Chanal Beel, North-Central Bangladesh. Variations in the b values may be atributed to differences in ecological conditions of the habits or variations in the physiology of animals, or both (Le Cren, 1951), sex season (Hossain et al., 2006), feeding rate, gonadal development and growth phase (Tarkan et al., 2006), behavior (active or passive swimmer) and water flow (Muchlisin et al., 2010).

The condition factor $(\mathrm{k})$ is an index reflecting interaction between biotic and abiotic factors in the physiological condition of the fishes (was calculated to assess fish health productivity of fish populations) (Royce, 1972; Effendi, 1997). Commercial, factor conditions have meaning meat quality and quantity of fish available to be eaten (Effendi, 1997). In this study, the condition factor obtained in the ranges of 0.67-1.17 and tends to fluctuate on size of the fish (Table 3). Other studies related to condition factor has been reported by Rahman et al. (2012) in Chanal Beel, North-Central Bangladesh, India. They found that the condition factor (k) for $P$. sophore ranges between 0.69-2.35. Le Cren (1951) opined that the relative condition factor is an indicator of general well-being of the fish. $\mathrm{K}$ was greater than one (1) expressed as indicative of the general well being of fish, whereas its value less than one (1) indicated that fish is not in a good condition. Small size of fish (juvenile) commonly has a higher condition factor and then decrease as the fish grows. It was associated with the changes in the type of food in the moment of growth (Effendi, 1997). In the early period of growth, the formation of cells and tissues in the body of fish required a lot of energy. This situation makes the fish eats as much as possible, so that the condition factor increases.

Other studies related to gonad maturity stage on red side barb (Puntius bimaculatus) has been reported by Wijeyaratne and Ponnamperuma (2005) in Sri Lanka. They found that the precentage abundance of different maturity stages I were recorded in June and July. Assessment of gonadal development is not only based on morphological characteristics because only be qualitatively explained thus less informative and subjectively. Yet in gonad development are not only morphological development but there is also the development of eggs and this occurs aligned with the development of gonad weight (Effendi, 1997; Lagler et al., 1977). Description of the development of eggs and gonad weight may provide additional information that can be described quantitatively. Sometimes the value of GSI is associated with gonad maturity which based on morphological characteristics gonad maturity.

\subsection{Histological Studies}

Pollutants such as industrial and agriculture wastes, pesticides (environmental estrogenic) and also different types of bacteria have histopathological effects on the reproductive tissue of fish gonads. These may disturb the development of germ cells and may reduce the ability of fish to reproduce, while metal accumulation occurring in the testis, affects the process of spermatogenesis and suppressing sperm production. Kumar and Pant (1984) found that 2-4 month exposure of an Indian teleost to lead caused disappearance of oocyes in the ovaries.Blazer (2002) also reported proliferation fibroblast in Cod (Gadus moruha) fed Aroclor, polychlorinated biphenyl. 
The presence of testis-ova in the gonads is indicating that fish is to be feminizing (Fig.3a and 3b). It can be occured because of disruption of endocrine function in fish which often called Endocrine Disrupting Chemical (EDC). Testis-ova are the most popular abnormal morphological change in fish exposed by estrogenic chemicals (Soyano et al., 2010; Jobling and Tyler, 2003). It is well known that testis-ova are induced by these chemicals in the fish that is sex determination phase, which occur during fly and larval stage (Soyano et al., 2010). EDCs in organisms was stimulated by the presence of pollution as a result of anthropogenic xenobiotics. Some polluting substances that can cause EDC is chemical waste from factories (Nonyphenol, bisphenol-A, PCBs, PAHs, dioxins, etc.) (Pait and Nelson, 2002; Sun and Tsai, 2009; Soyano et al., 2010; , the compounds of the class of pesticides (Carbofuran, Endosulfan, Lindane, DDT, DDE, etc.) (Pait and Nelson, 2002; Sumpter, 2002), heavy metals (Hg, Pb, and $\mathrm{Cd}$ ) and natural products (b-sitosterol, genistein, enterodiol, natural estrogenic) (Pait and Nelson, 2002; Jobling and Tyler, 2003; Sun and Tsai, 2009).

The presence of testis-ova in the gonads is indicating that fish is to be feminizing (Fig.3a and $3 b)$. It can be occured because of disruption of endocrine function in fish which often called Endocrine Disrupting Chemical (EDC). Testis-ova are the most popular abnormal morphological change in fish exposed by estrogenic chemicals (Soyano et al., 2010; Jobling and Tyler, 2003). It is well known that testis-ova are induced by these chemicals in the fish that is sex determination phase, which occur during fly and larval stage (Soyano et al., 2010). EDCs in organisms was stimulated by the presence of pollution as a result of anthropogenic xenobiotics. Some polluting substances that can cause EDC is chemical waste from factories (Nonyphenol, bisphenol-A, PCBs, PAHs, dioxins, etc.) (Pait and Nelson, 2002; Sun and Tsai, 2009; Soyano et al., 2010; ) the compounds of the class of pesticides (Carbofuran, Endosulfan, Lindane, DDT, DDE, etc.) (Pait and Nelson, 2002; Sumpter, 2002), heavy metals (Hg, Pb, and $\mathrm{Cd}$ ) and natural products (b-sitosterol, genistein, enterodiol, natural estrogenic) (Pait and Nelson, 2002; Jobling and Tyler, 2003; Sun and Tsai, 2009).

Living in the aquatic environment, fish can be bathed constantly in a solution of chemical pollutants (Hecker et al., 2006). Furthermore, uptake of chemicals into fish can readily occur via the gills and skin, as well as via diet (the major route of exposure to EDCs in terrestrial animals). Features of the gills including thin epithelial membranes and a large surface area coupled with the relatively high ventilation rates that occur in fish, facilitate the uptake of compounds from the water and their transfer into the blood stream (Marina and Martinez, 2007). Some freshwater fish species are also top-predators and thus, are likely to bioconcentrate EDCs to a greater degree than other organism at lower tropic levels (Bernet et $a l ., 2008)$. Freshwater fish are hypo-osmotic with their surroundings and thus a considerable movement of water into their bodies occurs down an osmotic gradient (taking chemicals with it). A major route of exposure to EDCs in fish during early life is from contaminants that have accumulated in lipid reserves within the egg as a consequence of maternal transfer during ovary development. These contaminants that have accumulated in the egg are mobilized when the lipid reserves are metabolized to fuel embryo development, exposing early life stages to especially high concentration of EDCs at a time of greatest vulnerability to disruptions in their developing endocrine system (Sumpter, 2002; Hecker et al., 2006; Soyano et al., 2010). 


\section{MInstitute Macrothink $_{\text {Int }}$}

Furthermore, early life stages of fish have a limited capacity to metabolize and excrete contaminants, including EDCs (Jobling and Tyler, 2003).

\section{Conclusion}

Based on these results, we conclude that endocrine disrupting effect on reproductive organ has been occurred in the Mas River, Surabaya. These effects is were indicated by the presence of defects in fish gonads. The defects include atretic oocyte on the ovary, degenerative, collapsing and necrotic changes in both the wall and the cellular elements of the seminiferous tubules with focal areas of fibrosis on the testis and edema. Some fish also showed intersex that characterized by the presence of testis-ova in the gonads.

\section{Acknowledgements}

The study was supported by DGHE, Ministry of National Education under International Research Collaboration No. 191/SP2H/PL/Dit.Litabnas/IV/2012.

\section{References}

Allen, K. R. (1938). Some observation on the biology of the trout (Salmo truta) in Windemere. J. Anim. Ecol. (7), 333-349. http://dx.doi.org/10.2307/1168

Allner, B. S. Gonna, E-V Griebeler \& N. Nikutowski. A. (2010). Reproductive functions of wild fish as bioindicators of reproductive toxicants in the aquatic evironment. Environ Sci Pollut Res, 17, 505-518. http://dx.doi.org/10.1007/s11356-009-0149-x

Archarya, P., \& M. B. Iftekhar. (2000). Freshwater Ichthyofauna of Maharashtra state: Endemic Fish Diversity of Western Ghats. A.NBFGR-NATP Publication. National Bureau of Fish Genetic Resources, Lucknow, U.P., India.

Batty, J., \& R. Lim. (1999). Morphological and reproductive characteristics of male Mosquitofish (Gambusia affinis holbrooki) inhabiting sewage-contaminated waters in New South Wales, Australia. Arch Environ Contam Toxicol, 36, 301-307. http://dx.doi.org/10.1007/s002449900475

Bayu, S. P. (1997). Penggunaan kelompok makrobenthos untuk menduga kualitas air di Mas Surabaya. Karya Ilmiah Fakultas Perikanan Universitas Brawijaya. Malang (unpublished).

Bernet, D., A.Liedtke, D. Bittner, R. I. L.Eggen, S. Kipfer, C. Kung, C. R. Larglader, M. J-F. Suter, T. Wahli \& H. Segner. (2008). Gonadal malformation in Whitefish from Lake Thun: Defining the case and evaluating the role of EDCs. Endocrine Disruptors: Natural Waters and Fishes. Chimia, 62(5), 383-386. http://dx.doi.org/10.2533/chimia.2008.383

Blazer, V. S. (2002). Histopathological assessement of gonadal tissue in wild fishes. J.Fish Physiology and Biochemistry, 26, 85-101. http://dx.doi.org/10.1023/A:1023332216713

ECOTON. (2011). Inventarisasi Keanekaragaman Jenis Ikan di Kali Brantas 2011 (Segmen Brantas Tengah Kediri, Nganjuk, Jombang, Mojokerto dan Gresik). Draft Laporan Peneliti

Effendi, M. I. (1997). Biologi Perikanan. Yayasan Pustaka Nusatama. Bogor. 157 p. 
Fatimah, L. Beberapa aspek reproduksi ikan kresek (thryssa mystax) pada bulan Januari-Juni di perairan Ujung Pangkah, Jawa Timur [Research]. Department of Water Resources Management. Faculty of Fishery and Marine Science. ITB. Bogor

De Robert. A., \& K. William. (2008). Weight-Length relationship in fisheries studies: The standard allometric model should be applied with caution. Transaction of the American Fisheries Society, 137, 707-719. http://dx.doi.org/10.1577/T07-124.1

Hecker. M, M. B. Murphy, K. K. Coady, D. L. Villeneuve, P. D. Jones, J. A. Carr, K. R. Solomon, E. E. Smith, G. V. D. Kraak, T. Gross, L. D. Preez, R. J. Kendall \& J. P. Giesy. (2006). Terminology of Gonadal Anomalies in Fish and Amphibians Resulting from Chemical Exposure. Rev Environ Contam Toxicol, 187, 103-131. http://dx.doi.org/10.1007/0-387-32885-8_3

Hegrenes, S. (1999). Masculinization of spawning channel catfish in the red river of the north. Copeia 2, 491-494. http://dx.doi.org/10.2307/1447497

Hossain, M. Y. (2010). Morphometric relationship of length-weight and length-length of four Cyprinid small indigemous fish species from the Padma River (NW Bangladesh). Turkish Journal of Fisheries and Aquatic Science, 10(1), 213-216.

Howell, W. M., D. A. Black \& S. A. Bortone. (1980). Abnormal expression of secondary sex characters in a population of Mosquitofish, Gambusia affinis holbrooki: Evidence for enviromentally-induced mascuninization. Copeia 4, 676-681. http://dx.doi.org/10.2307/1444443

Jobling, Susan \& C. R. Tyler. (2003). Endocrine disruption in wild freshwater fish. Pure Appl. Chem, 75, 11-12. http://dx.doi.org/10.1351/pac200375112219

Kumar, S., \& S. C. Pant. (1984). Comparative effect of sublethal poisoning of zinc, copper and lead on the gonads of teleost Puntius conchofus Ham. Toxicol, 23, 189.

Lagler, K. F, J. E. Bardach, R. R. Miller \& D. R. May Passino. (1977). Ichthyology: The study of fishes. John Willey and Sons. New York.

Le Cren, E. D. (1951). The length-weight relationship and seasonal cycle in gonad weight and condition in the perch (Perca fluviatilis). Journal of Animal Ecology, 20(2), 201-219. http://dx.doi.org/10.2307/1540

Marina, M. P. C \& C. B. R. Martinez. (2007). Histopathology of gills, kidney and liver of a Neotropical fish caged in an urbanstream. Ncotropical Ichtyology, 5(3), 327-336. http://dx.doi.org/10.1590/S1679-62252007000300013

Mazrouh, M \& A. Mahmoud. (2009). Some aspect of reproductive biology with emphasis on the effect of pollution on te histopathological stucture of Gonads in Oreochromis niloticus from Rosetta Branch, Nile River, Egypt. World Journal of Fish and Marine Science, 1(3), 190-198.

Muchlisin, Z. A, M. Musman \& M. N. S. Azizah. (2010). Length-weight relationship and condition factors of two threatened fishes, Rasbora tawarensis and Poropuntius tawarensis, 
endemic to Lake Laut Tawar, Aceh Province, Indonesia. Journal of Applied Ichthyology, 26(6), 949-953. http://dx.doi.org/10.1111/j.1439-0426.2010.01524.x

Okgerman, H. (2005). Seasonal variation of the length weight and condition factor of Rudd (Scardinus erythrophthalmus L) in Spanca Lake. International Journal of Zoological Research, 1(1), 6-10. http://dx.doi.org/10.3923/ijzr.2005.6.10

Pait, A. S \& J. O Nelson. (2002). Endocrine Disruption in Fish. An Assessement of Recent Research and Result. Centre for Coastal Monitoring and Assessement. National Centres for Coastal Ocean Science. National Ocean Service US.

Peraturan Pemerintah (PP) Republik Indonesia no 82, (2001). Pengelolaan Kualitas Air dan Pengendalian Pencemaran Air.

Putri, N. A, N. Abdulgani, \& I. Trisnawati. (2011). Biomonitoring in situ Mas Surabaya menggunakan Perubahan Histopatologis Insang Ikan Mujair (Oreochromis mossambicus). [Research] Department of Biology, Faculty of Mathematics and Natural Sciences, ITS, Surabaya.

Rahman, M. M, M. Y. Hossain, M. A. S. Jewel, M. M. Rahman, S. Jasmine, E. M. Abdallah \& J. Ohtomi. (2012). Population structure, length-weight and length-length relationship and condition-and form-factors of the Pool barb (Puntius sophore) (Hamilton, 1822) (Cyprinidae) from Chalan Beel, North-Central Bangladesh. Sains Malaysiana, 41(7), 795-802.

Risjani, Y, S. Sudaryanti, D. Batoro, E. Yuli. A, M. Musa, D. Arfiati \& Yunianta. (1988). Biodiversity inventory survey of The Brantas River: The study on comprehensive management plan for the water resources of The Brantas River Basin in the Republic of Indonesia. Faculty of Fisheries. Brawijaya University. Malang.

Risjani, Y, S. Musliha, A. Hermawati, J. Couteau \& C. Minier. (2012). Assesement of fish health status in the Brantas River, Indonesia. Comparative Biohemistry and Physiology, Part A: Molecular \& Integrative Physiology, 163, S42.http:dx.doi.org/10.1016/j.cbpa.2012.05.125

Royce, W. F. (1972). Introduction to The Fishery Science. Academic Press. New York. 428 p.

Rypel, A. L \& T. J. Ritcher. (2008). Emperical percentile standard weight equation for the Blacktail Redhorse. North America Journal of Fisheries Management, 28, 1843-1846. http://dx.doi.org/10.1577/M07-193.1

Siregar. S, R. M. Putra \& Sukendi. (1993). Fauna ikan di perairan sekitar Bukit Tigapuluh, Siberida, Sumatra. Rain Forest and Resource Management. Procedings of NORINDA.

Slamet, B., K. Suwirya, A. I. Supii \& I. Setyadi. (2010). Beberapa aspek biologi reproduksi ikan Kerapu Raja Sunu (Plectropoma laevis). Prosiding Forum Inovasi Teknologi Akuakultur 2010, 351-357.

Soyano, K. Jun-ya Aoki, Y. Itashiki, K. Don Lee, In-Kyu Yeo \& J. Zhong. (2010). Contaminant by endocrine disrupting chemicals in coastal waters of the east China sea. Coastal Environmental and Ecosystem Issues of the East China Sea, Eds.,A.Ishimatsu and 
H-J.Lie, 215-226.

Sumpter. J. P. (2002). Endocrine Disruption in the Aquatic Encironment. The Handbook of Environmental Chemistry Vol. 3, Part M Endocrine Disruptors, Part II. Springer. Berlin.

Sun, P. T \& S. Tsai. (2009). Intersex Tilapia (Oreochromis spp.) from a contaminated river in Taiwan: a case study. Article. Toxins, l. 15-24.

Tarkan, A. S, O. Gaygusuz, P. Acipinar, C. Gursoy \& M. Ozulug. (2006). Length-weight relationship of fishes from the Marmara region (NW-Turkey). Journal of Applied Ichthyology, 22(4), 271-273. http://dx.doi.org/10.1111/j.1439-0426.2006.00711.x

Wijeyaratne, M. J. S., \& K. Ponnamperuma. (2005). Reproductive biology and population dynamics of red side barb ( $P$. bimaculatus), an indigenous Cyprinid in Sri Lanka. Cey.J.Sci.(Bio.Sci), 3, 55-65.

\section{Copyright Disclaimer}

Copyright reserved by the author(s).

This article is an open-access article distributed under the terms and conditions of the Creative Commons Attribution license (http://creativecommons.org/licenses/by/3.0/). 